\title{
A Current Controlled DEC-DTC Approach for QZSI-FED Five-Phase Induction Motor Drive System
}

\author{
Richa Pandey ${ }^{1}$, Anup Kumar Panda ${ }^{2}$ and Nishant Patnaik ${ }^{3}$ \\ ${ }^{1}$ Dept. of EEE, MVGRCE, Vizianagaram, India, ${ }^{2}$ Dept. of EE, NIT Rourkela, Rourkela, India \\ ${ }^{3}$ Dept. of EEE, ANITS, Visakhapatnam, India
}

\begin{abstract}
This paper basically proposes a current controlled dynamic evolution control (DEC) based direct torque control (DTC) approach for qZSI fed five-phase induction motor (IM) drive system. Since, multi-phase drives are applicable for special and sensitive application, supply disruption in the form of sag is a severe problem. A qZSI offers numerous advantages over conventional one, such as boosting the output DC voltage $\left(\mathrm{V}_{\mathrm{O}}\right)$, utilising the shoot-through state of the inverter switches and avoids delay time between switches of inverter's each leg. These advantages are utilized effectively in a controlled manner to efficiently sustain the operation of multi-phase IM drive even under voltage sag conditions. A non-linear control function, i.e. DEC based duty cycle " $D$ " generation method is proposed to utilize the shootthrough state of qZSI, for output DC voltage $\left(\mathrm{V}_{\mathrm{O}}\right)$ control, thus improving the torque and speed response of the drive. Also, the proposed control scheme plays a major role in source current harmonic reduction, thus maintaining the THD content and power factor at the supply end. An experimental analysis is carried out to justify the efficacy of the proposed current controlled DEC-DTC approach for qZSI fed five-phase IM drive.
\end{abstract}

Index Terms - DEC (Dynamic evolution control), DTC (Direct torque control), qZSI (quasi Zsource inverter), SVM (Space vector modulation)\

\section{Introduction}

The ground-breaking progression in $\mathrm{AC}$ drive applications is mainly due to rise in performance and economic features of power electronic devices. The use of multi-phase drive system is one such important advancement in this area. They offer significant advantages such as their fault tolerant capability, high torque density, etc. over the conventional three-phase drives. Their noteworthy superiority over the conventional drive has forced the researchers to further explore its characteristics [1]-[4]. The use of power electronic converters has made their supply and control structure easily feasible. This aspect has made their use with obvious benefits in areas such as electric aircraft, ship propulsion systems, electric vehicles and electric traction system etc. [1], [4]-[6]. The most significant advantage offered by the multi-phase drive is its fault tolerant capability, which in turn is important for applications concerned with critical-safety [7]. Moreover, some distinct advantages are obtainable by multi-phase drives over three-phase like increase in torque density, reduced torque pulsations, enhanced noise characteristics etc. [3], [8].

These multi-phase drives are necessarily supplied and governed through a power converter as the ac power supply accessible is typically of three-phase nature. Thus, based on the specific machine phases, relevant power converter, i.e. inverter is implemented with respective legs. This inverter fed machine drive results in substantial harmonics in the source current, thereby hampering the power factor at the supply end and voltage profile for other connected loads. The multi-phase drive find itself suitable for critical areas, due to its higher power management capacity under fault state and therefore are more susceptible to any disruption from the source. The issues associated with an $\mathrm{AC}$ drive system are linked from both ends, i.e. source side and load side, one side getting affected due to the other. One of the problem is effects on machine drive performance due to supply variations and second is pollution of source end in the form of

Received: November $25^{\text {th }}, 2018$. Accepted: June $3^{\text {rd }}, 2020$

DOI: $10.15676 /$ ijeei.2020.12.2.13 
severe injection of current harmonics, thus affecting the voltage profile and results in reduction of power factor. These issues can be addressed with the proposed CC-DEC based qZSI (quasi Z-Source Inverter) fed drive system. Thus, performance of a qZSI fed multi-phase drive as discussed in this paper, is not only suitable for application in a non-ideal supply environment, but also avoids their contribution in electric pollution and improves the power factor.

A ZSI ( $Z$ source inverter) is a suitable front-end power converter for AC drive applications as compared to conventional converters [16]-[21]. A ZSI has several advantages like eliminating shoot-through phenomenon, endures voltage disruption from the source, increases the efficiency and system reliability, sustains the system voltage, etc. The conFigureuration of ZSI is possible in different ways, conditional to their application for motor drive [16]. From all the topologies available, a qZSI (quasi ZSI) is more promising due to benefits such as components with lower rating, common-mode noise reduction input current of continuous nature etc. [16], [17].

A ZSI based drive system typically comprises of two inter-related control structures as their control conFigureuration. One is the duty cycle (D) control for non-shoot through and shootthrough states of inverter and other is the motor control structure. The performance control conFigureuration of AC drives mostly involves FOC (field oriented control) or DTC (direct torque control) for three-phase or multi-phase machines. Nevertheless, DTC is a more prevalent and broadly accepted alternative due to several reasons, as observed by the researchers [22]- [27].

In view of non-linearities and uncertainties and being introduced from both load end and supply end (motor-load system), In this paper, a DEC (Dynamic evolution control) approach is proposed in this paper for simultaneous control of DC voltage available for inverter conFigureuration and THD reduction of source current. The DEC approach proves to be an effective technique that can be used under transient conditions for the minimization of errors and for the precise control [28]. This technique effectively controls and boosts DC voltage when implemented for PFC converter [29]. Henceforth, a duty cycle algorithm is formulated built on DEC method for this particular arrangement and working conditions of qZSI. The produced duty cycle is unified alongwith DTC for proposed qZSI fed five-phase induction motor drive system. The proposed drive system is analyzed for its effectiveness under conditions of voltage sag and voltage interruption. The drive system is analyzed with experimental prototype for voltage sag condition and simulation analysis is carried out for interruption condition.

\section{Quasi Z Source Inverter (qZSI)}

Figure 1 illustrates the qZSI implemented in the proposed system. The qZSI comprises of a two level five-phase inverter with IGBT as a switching device and a $Z$ network. This $Z$ network is a combination of various circuit elements, i.e. inductor, capacitor and diode. Figure 2 depicts two modes of operation for qZSI. Analogous to the conventional voltage source inverter (VSI) operating states, i.e. six active and two zero states, Figure. 2(a) illustrates the qZSI non-shoot-through state. When observed from the input side, it can be expressed as a current source at the output. The non-operating and unnecessary state of VSI (same leg switches being $\mathrm{ON}$ at the same time) is illustrated in Figure. 2(b), as the non-shoot through state of qZSI. When observed from inout end, it appears as a short circuit at the output. This shoot-through state is conceptualized with the help of $\mathrm{Z}$ network existing before the inverter switch combination. Consequently, this results in boost of output DC voltage $\left(\mathrm{V}_{\mathrm{O}}\right)$ and aids in eluding the deliberation of dead time introduction between switching of same leg switches. Therefore, the reliability of the system escalates greatly, owed to this supplementary shootthrough operation mode. 


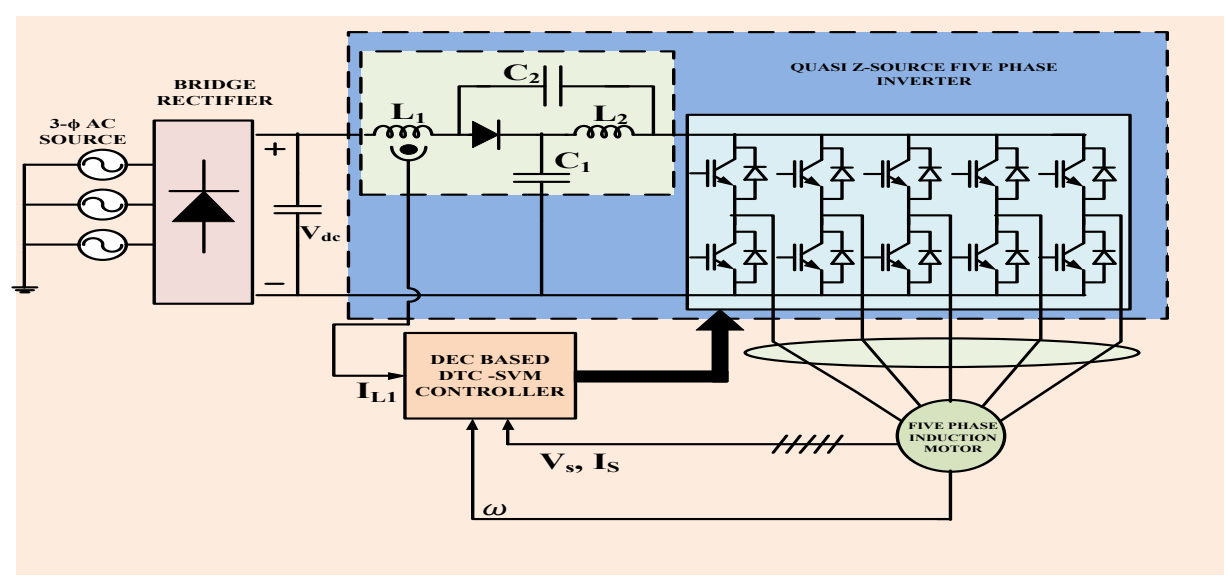

Figure 1. A qZSI fed five-phase induction motor drive system with DEC based DTC-SVM controller

The peak DC output voltage available for inverter bridge is given as:

$$
V_{0, \max }=\frac{1}{1-2 D} V_{i n}=G V_{i n}
$$

where $\mathrm{G}$ is the Gain Factor.

Eq. (1) clearly indicates that qZSI

It is evident from eq. (1), the qZSI is appropriately useful considering large deviation of voltage at supply side since it helps in realizing buck or boost operation of input voltage, accordingly. Consequently, it is also useful with external autonomous sources (usually that provides DC supply) such as fuel cell, photo-voltaic cell, etc. Moreover, there are few exclusive features of qZSI such as continuous input current, no control action requirement in $\mathrm{Z}$ network (as no control switch in $\mathrm{Z}$ network) and mutual terminal among source and inverter thereby, decreasing the electromagnetic interference. These qualities of qZSI are useful for such systems.

\section{Proposed Duty cycle estimation of "shoot-through-state" for qZSI using DEC algorithm}

A. Dynamic characteristic equation based on qZSI

Referring Figure. 2(a), considering non-shoot-through state, equations for voltage and current are given as [16]:

$$
\begin{aligned}
& C_{1} \frac{d v_{D_{11}}}{d t}=i_{L 1}-i_{0} \\
& C_{2} \frac{d D_{L 2}}{d t}=i_{L 2}-i_{0}
\end{aligned}
$$

Here $i_{L 1}, i_{L 2} \& i_{0}$ are respective currents flowing through $\mathrm{Z}$ network inductors $\mathrm{L}_{1}, \mathrm{~L}_{2}$ and DClink.

$v_{C 1}$ and $v_{C 2}$ are the voltages across capacitor $C_{1}$ and $C_{2}$ respectively.

$V_{\text {in }}$ is the voltage offered at the input end of qZSI.

Similarly, from Figure 2(b) voltage and current equations for shoot-through state are given as:

$$
C_{1} \frac{d V_{61}}{d t}=-i_{L 2}
$$




$$
C_{2} \frac{d D_{k 2}}{d t}=-i_{L 1}
$$

From eq. (2) and (3)

Assuming "T" as the total time period, say " $\mathrm{T}_{\mathrm{ST}}$ " is the period of shoot-through and " $\mathrm{T}_{\mathrm{NST}}$ " is the period of non-shoot-through state. Henceforth, $\mathrm{T}=\mathrm{T}_{\mathrm{ST}}+\mathrm{T}_{\mathrm{NST}}$ and the duty cycle can be given as:

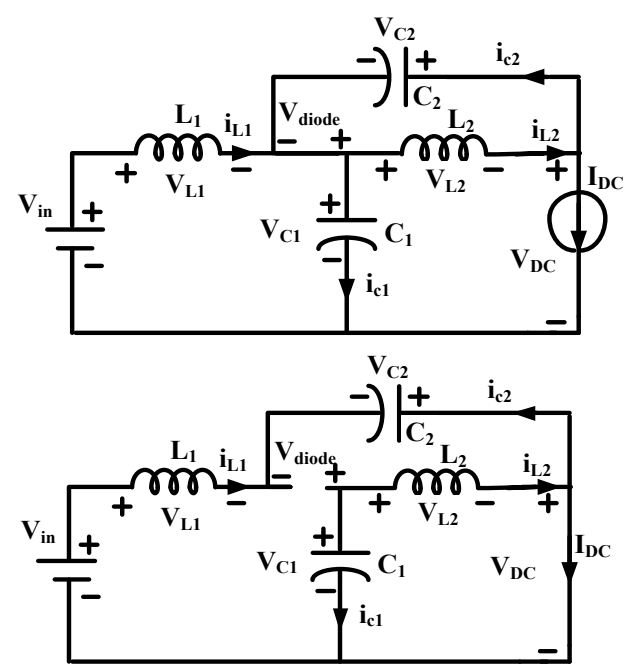

(a) (b)

Figure 2. Equivalent circuit of qZSI (a) non-shoot-through state (b) shoot-through state

$$
D=\frac{T_{S Y}}{T}
$$

Since, eq. (2) and eq. (3) relates to non-shoot-through and shoot-through state correspondingly, these equations are revised as:

$$
\begin{aligned}
& T_{N S T}\left(C_{1} \frac{d v_{c 1}}{d t}+C_{2} \frac{d v_{c 2}}{d t}\right)=\left(i_{L 1}+i_{L 2}-2 i_{0}\right) T_{N S T} \\
& T_{S T}\left(C_{1} \frac{d v_{c 1}}{d t}+C_{2} \frac{d v_{c 2}}{d t}\right)=-T_{S T}\left(i_{L 1}+i_{L 2}\right)
\end{aligned}
$$

From eq. (15) and (16),

$$
T\left(C_{1} \frac{d v_{c 1}}{d t}+C_{2} \frac{d v_{c 2}}{d t}\right)=-\left(T_{N S T}-T_{S T}\right)\left(i_{L 1}+i_{L 2}\right)-2 i_{0} T_{N S T}
$$

Thus, the duty cycle " $\mathrm{D}$ " is expressed in the dynamic characteristic equation as:

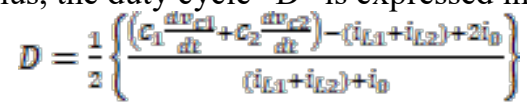

\section{B. Derivation of duty cycle " $D$ " expression using DEC algorithm}

The error-state variable $Y$ and current error variable $i_{L 1, E r}$ are related in a linear manner as:

$$
Y=k i_{L 1, e r}
$$

Where $k$ is termed as positive coefficient. Also, $i_{L 1_{1} e V}=i_{L 1 \text { ref }}-i_{L 1}$

Assuming, an exponential track to be a function of the evolution path, the error-state variable $Y$ diminishes to zero as:

$$
Y=Y_{0} e^{-m t}
$$


Here, initial value is stated as $Y_{0}$ and $\mathrm{m}$ is the system design variable ( $\mathrm{m}$ controls the rate of evolution) also, $\mathrm{m}>0$.

When eq. (20) is differentiated, we get:

$$
\frac{d Y}{d t}+m Y=0
$$

The error-state variable $\mathrm{Y}$ is substituted from eq. (12) to eq. (13):

$$
\begin{aligned}
& k \frac{d i_{L_{1} a r}}{d t}+m k i_{L I_{1} \theta Y}=0 \\
& k \frac{d i_{L 1, E x}}{d t}+(m k-1) i_{L 1, e r}+i_{L 1, r e f}=i_{L 1}
\end{aligned}
$$

From eq. (10) and eq. (15), the duty cycle "D" of shoot-through state is obtained for qZSI. " $D$ " is then unified with SVM for producing switching pulse, to be given to qZSI.

\section{Control implementation for five-phase IM using DEC-DTC technique}

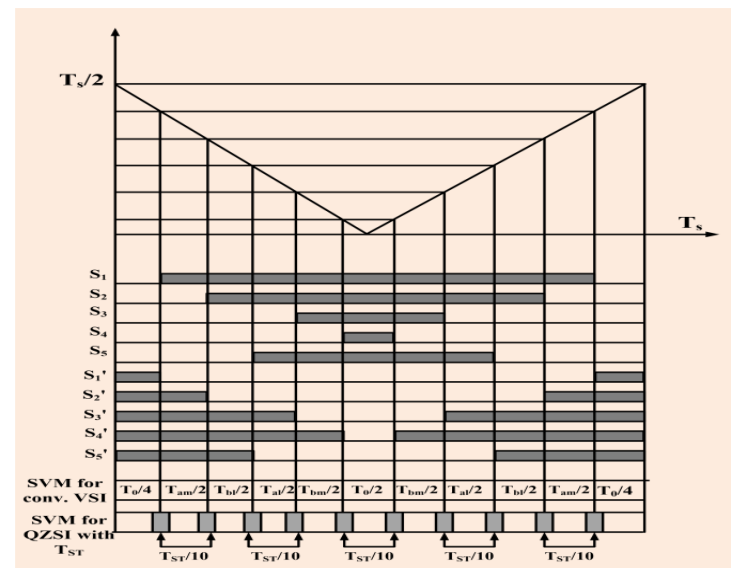

Figure. 3 Switching sequence pattern for conventional inverter and qZSI

The DTC algorithm is quite popular and extensively adopted method of governing high performance drives. The research fraternity have well taken note of its various benefits and importance over other techniques. Also, for multiphase drives, DTC method suffice an ease of applicability. The generated duty cycle " $\mathrm{D}$ " is suitably unified with space vector modulation (SVM) scheme of DTC [15]. Various SVM algorithms are established in [13] in reference to five-phase qZSI, amongst which SVQ5 is chosen in the proposed work, as is stated to be superior than others. Depending on the required DC output voltage $\left(\mathrm{V}_{\mathrm{O}}\right)$ and the switching time period $(\mathrm{T})$, the shoot-through application on each leg of five-phase inverter is realized. In this paper, the SVM algorithm is realized by accomplishing switching among two active and two zero vectors for precise duration in a particular sector.

Among ten switches of five-phase inverter, the shoot-through existing time is distributed alike for individual switching duration. Furthermore, for upper and lower set of switches, similar partition of shoot-through duration is retained. Figure. 3 illustrates the switching behavior for a particular sector (sector 1). The switching behavior for upper and lower switches are $S_{1}, S_{2}, S_{3}, S_{4}, S_{5}$ and $S_{1}^{s}, S_{2}^{s}, S_{3}^{s}, S_{4}^{s}, S_{5}^{s}$ respectively. The shoot-through time duration is assumed same as average zero vector time duration. The voltage and current waveform will be disturbed if the shoot-through duration is higher than the zero vector time duration, upsetting the performance of the drive system. Therefore, for one switching cycle for sector 1 , the maximum value of shoot-through duty ratio is expressed as [15]: 


$$
D_{\max }=1-\frac{1.91}{\pi} \sigma(1+k)
$$

The block diagram of DEC-DTC based controller for qZSI fed five-phase IM drive is depicted in Figure. 4. The torque and flux are calculated by using the fed back quantities of stator voltage and current. Moreover, these fed back signals are also used for sector selection $\left(\theta_{\mathrm{S}}\right)$.

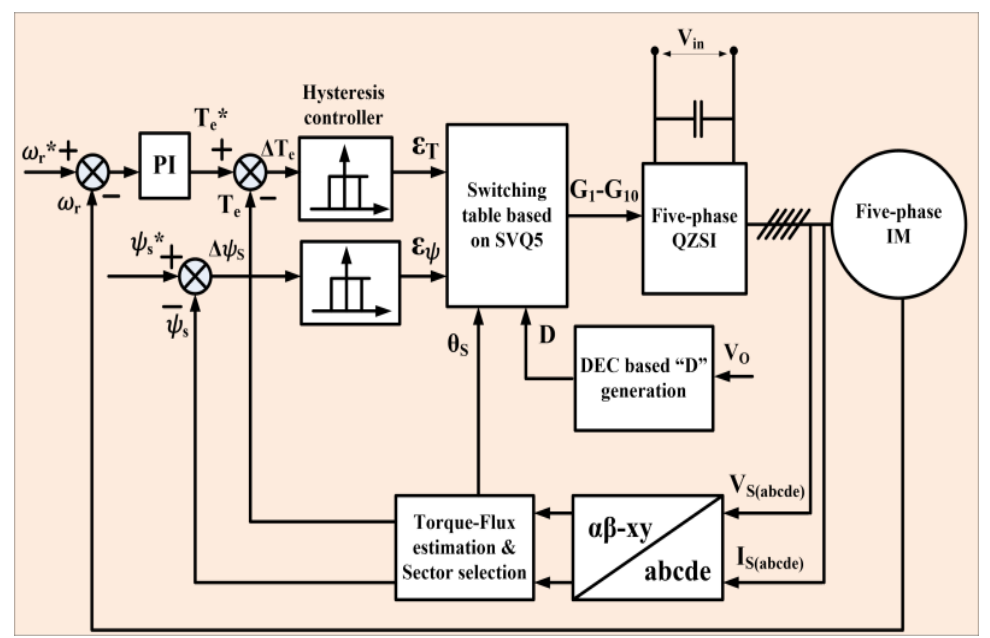

Figure 4. DEC-DTC based controller for qZSI fed five-phase IM drive

Reference torque and flux signals are equated with the assessed torque and flux values. The torque and flux error signals are given to two-level and three-level flux and torque hysteresis controller, correspondingly. Based on DEC algorithm, the duty cycle "D" is estimated as shown in the previous section. Depending on the value of "D" and based on SVQ5, the shootthrough duration is realized in all legs of the inverter. Henceforth, from the switching table gate switching signals $\left(\mathrm{G}_{1}-\mathrm{G}_{10}\right)$ are produced and applied to IGBT switches of qZSI.

\section{Result Analysis}

An experimental investigation of the qZSI fed five-phase IM drive is carried out to investigate the efficacy of proposed CC-DEC based DTC-SVM control. The performance of proposed drive system is analyzed considering source voltage sag condition, thus emphasizing the inherent voltage boost capability of qZSI and observing the power factor improvement at the supply end in response to the application of current controlled DEC scheme for qZSI. The proposed drive system is helpful for such applications which predominantly depends on continuous power supply, along with an appropriate boost in offered DC voltage.

\section{A. Experimental analysis}

Figure 5 illustrates the experimental conFigureuration for the drive system under consideration. The controlled qZSI system supplies the five-phase IM and load. Load set comprises of a DC generator with a resistive load. Two Semikron manufactured IGBT based three-phase inverter and the Z-network setup constitutes the qZSI arrangement. A five-phase inverter is realized by unifying three legs of one inverter (Inverter-1) and two legs of second inverter (Inverter-2. These inverters contain IGBT modules-SKM75GB123D and IGBT drivers-SKHI 22AR. Three-phase supply is given through three-phase autotransformer to a diode-bridge three-phase rectifier (part of inverter module). 


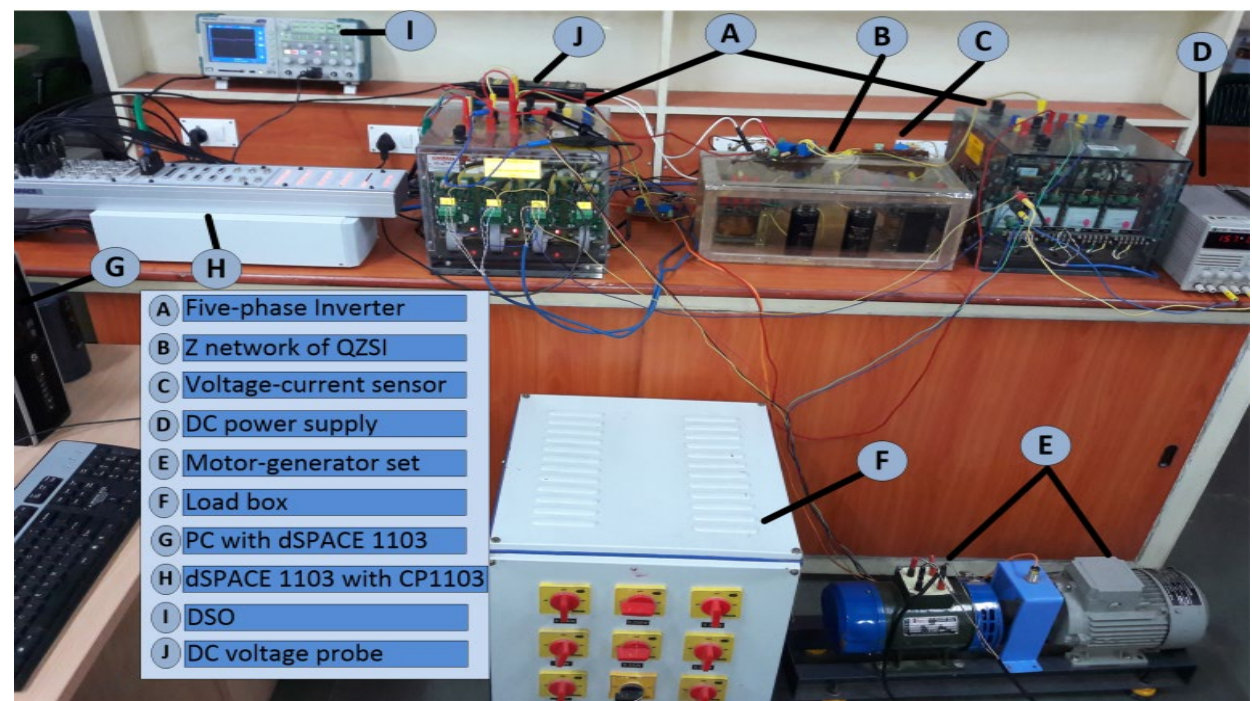

Figure 5. Experimental setup for proposed DEC-DTC based qZSI fed five-phase IM drive

Table 1. Experimental Parameters

\begin{tabular}{|c|c|c|}
\hline \multirow{12}{*}{$\begin{array}{l}\text { Five-phase } \\
\text { induction } \\
\text { motor }\end{array}$} & Rated power & $745 \mathrm{~W}$ \\
\hline & Rated phase-voltage & RMS $230 \mathrm{~V}, \mathrm{f}=50 \mathrm{~Hz}$ \\
\hline & Rated current & $1.75 \mathrm{~A}$ \\
\hline & Rated torque & $4.8 \mathrm{~N}-\mathrm{m}$ \\
\hline & Rated speed & $1480 \mathrm{rpm}$ \\
\hline & Pair of poles $(\mathrm{P})$ & 2 \\
\hline & Stator resistance $\left(r_{\mathrm{s}}\right)$ & $0.8 \Omega$ \\
\hline & Rotor resistance $\left(r_{r}\right)$ & $0.6 \Omega$ \\
\hline & $\begin{array}{l}\text { Self inductance od } \\
\text { stator }\left(\mathrm{L}_{\mathrm{ls}}\right)\end{array}$ & $2.5 \mathrm{mH}$ \\
\hline & $\begin{array}{l}\text { Self inductance of rotor } \\
\qquad\left(\mathrm{L}_{1 \mathrm{l}}\right)\end{array}$ & $2.5 \mathrm{mH}$ \\
\hline & Mutual inductance $\mathrm{L}_{\mathrm{m}}$ & $151 \mathrm{mH}$ \\
\hline & Inertia of rotor $(\mathrm{J})$ & $0.046 \mathrm{~kg} / \mathrm{m} 2$ \\
\hline \multirow{4}{*}{$\begin{array}{l}\text { Quasi } \quad \text { Z- } \\
\text { Source } \\
\text { Inverter }\end{array}$} & L1, L2 & $2.6 \mathrm{mH}$ \\
\hline & $\mathrm{C} 1, \mathrm{C} 2$ & $2000 \mu \mathrm{F}$ \\
\hline & Voltage boost factor & 1.45 \\
\hline & Frequency of switching & $10 \mathrm{kHz}$ \\
\hline
\end{tabular}

The Z-network arrangement is supplied from the rectifier output DC-link voltage. Thereafter, the Z-network DC output voltage is given to the inverter part of qZSI system. The five-phase input for the five-phase IM is supplied from three output terminals of one inverter (Inverter-1) and two from the second inverter (Inverter-2). dSPACE 1103 is used to implement the controller for the qZSI system as depicted in Figure. 5. Hall effect current and voltage transducers, i.e. LA 55-P and LEM LV 25-P are used to sense the stator phase voltage and currents, correspondingly. A voltage probe is used to sense the Z-network DC output voltage. A speed encoder is utilized to detect the motor speed coupled between IM and DC generator. The analog sensed signals are given to the connector panel CP1103 through ADC (Analog to Digital Converter) channels. The proposed CC-DEC based DTC technique is realized with Simulink and the switching signals so produced are sent through CP1103, to the drivers of IGBT switches of inverter. TABLE I illustrates the experimental parameters. 
Richa Pandey, et al.

\section{Voltage sag condition}

A source voltage sag condition is considered for the experimental analysis. Depending on the fault, a voltage sag can be categorized into different types, amongst whom type-C is observed as the most affecting sag condition [9]. Henceforth, the performance of proposed five-phase induction motor drive system is investigated for the C-type voltage sag condition.

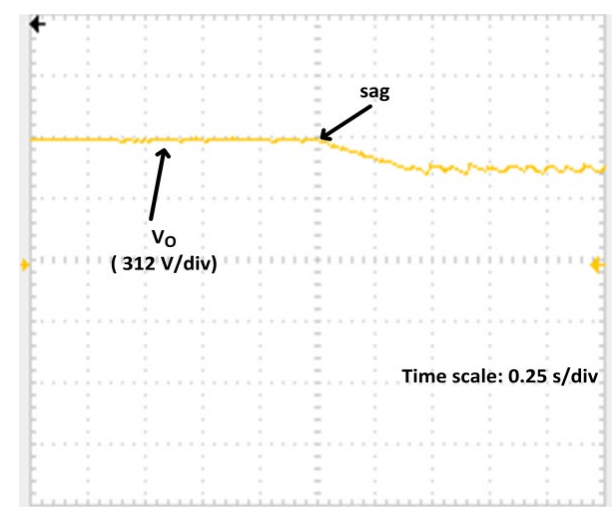

a. DC-link voltage

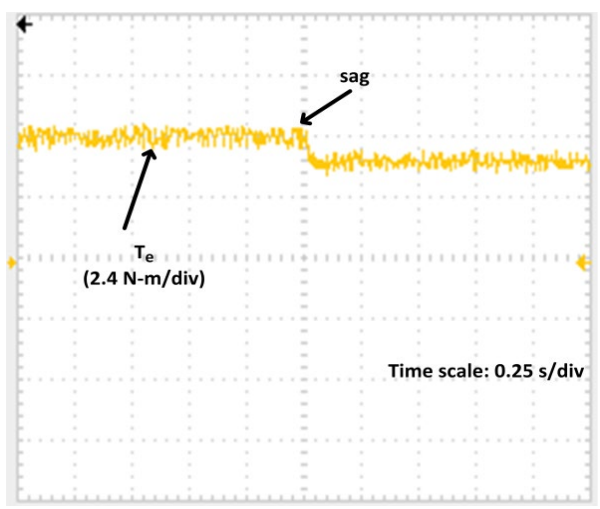

b. Estimated Torque

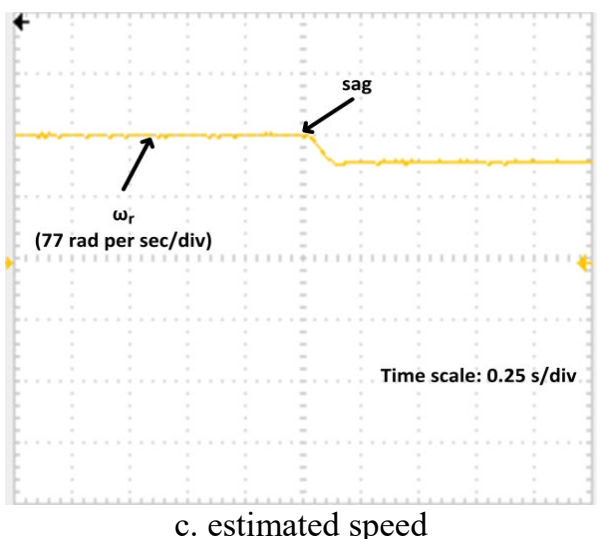

Figure 6. Five-phase IM drive performance characteristic considering voltage sag condition with DTC based conventional inverter 


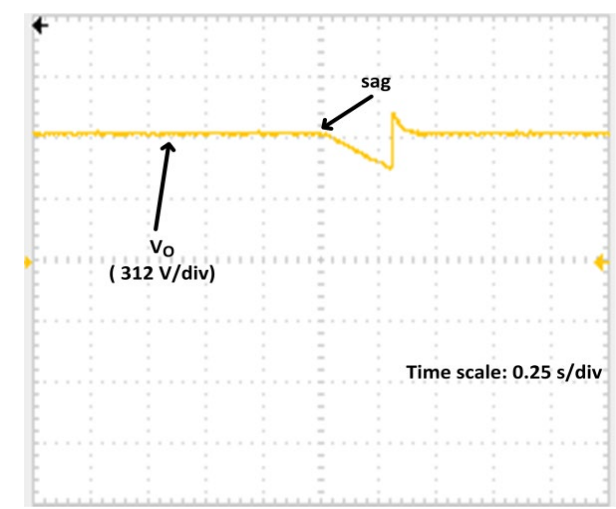

a. DC-link voltage

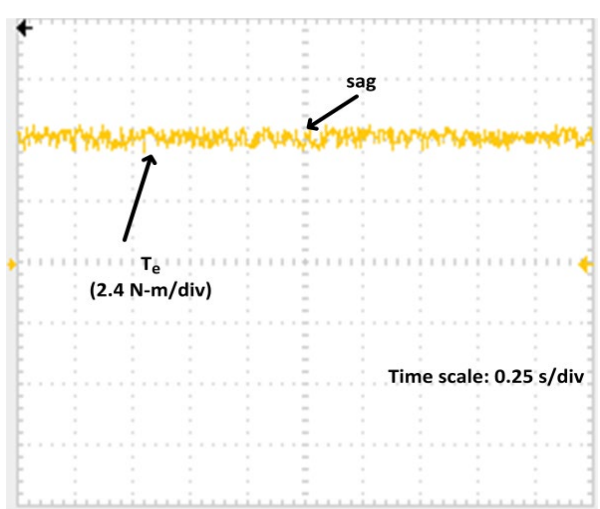

b. Estimated Torque

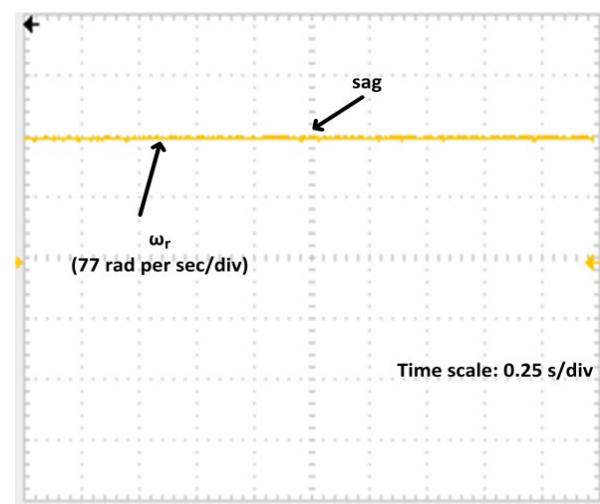

c. Estimated Speed

Figure 7. Five-phase IM drive performance characteristic considering voltage sag condition with proposed DEC-DTC based qZSI

The response for conventional inverter and qZSI, considering type- $\mathrm{C}$ voltage sag condition are shown in Figure. 6 and Figure 7 respectively. Figure. 6(a) shows the waveform for DC-link voltage (VO) in case of conventional inverter. The voltage sag results in around $25 \%$ reduction in DC-link voltage. Also, a drop of around $20 \%$ is registered in the motor torque (Te) as shown in Figure. 6(b). This clearly indicates that voltage sag thus affects the motor response quite evidently. The motor speed $\left(\omega_{0}\right)$ also reduces by around $20 \%$ as shown in Figure. 6(c) due to the sag phenomena. The DC-link voltage (VO) for qZSI, controlled with proposed CCDEC based DTC-SVM, is shown in Figure 7(a). The DC-link voltage is sustained at its set 
reference value even under sag condition as evident from the waveform. Figure 7(b) clearly indicates the torque (Te) to be maintained constant. Furthermore, the speed response ( $\omega r$ ) of the motor is also sustained at its rated value after the sag condition as illustrated in Figure 7(c).

A relative analysis is illustrated in TABLE II with the inferred deductions observed from the results. The impact of voltage sag condition on motor drive is quite severe, somewhat to a higher extent with conventional inverter, as observed from the comparison. Therefore, the suggested CC-DEC based DTC technique for qZSI fed five-phase IM drive is observed to be fairly promising under voltage sag condition.

Table 2. Comparative Performance Analysis under SAG Condition

\begin{tabular}{|c|c|c|}
\hline $\begin{array}{c}\text { PERFORMANCE } \\
\text { PARAMETER }\end{array}$ & CONVENTIONAL & $\begin{array}{c}\text { QUASI-Z SOURCE } \\
\text { INVERTER WITH } \\
\text { PROPOSED } \\
\text { CONTROLLER }\end{array}$ \\
\hline OUTPUT DC VOLTAGE $\left(\mathrm{V}_{\mathrm{O}}\right)$ & $\begin{array}{c}\text { Reduced and settled at } 25 \% \\
\text { after } 0.5 \mathrm{~s}\end{array}$ & $\begin{array}{c}\text { Settles at the same value } \\
\text { after } 0.4 \mathrm{~s}\end{array}$ \\
\hline ESTIMATED TORQUE $\left(\mathrm{T}_{\mathrm{e}}\right)$ & $\begin{array}{c}\text { Reduced and settled at } 20 \% \\
\text { after } 0.1 \mathrm{~s}\end{array}$ & $\begin{array}{c}\text { Response is similar after } \\
0.5 \mathrm{~s}\end{array}$ \\
\hline MOTOR SPEED $\left(\omega_{\mathrm{r}}\right)$ & $\begin{array}{c}\text { Reduced and settled at } 20 \% \\
\text { after } 0.125 \mathrm{~s}\end{array}$ & No change observed \\
\hline
\end{tabular}

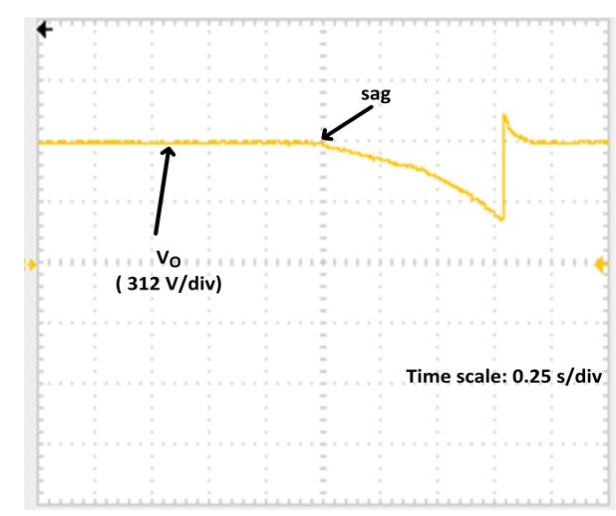

a. DC-link voltage

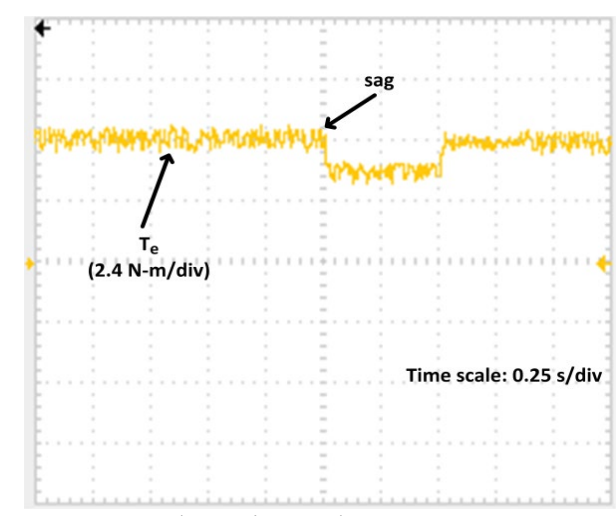

b. estimated torque

Figure 8. Five-phase IM drive performance characteristic considering voltage sag condition with PI-DTC based qZSI 
Moreover, response of the drive system for voltage sag condition is observed using PI controllers for output DC voltage control (VO), i.e PI-DTC. After a transient period of $0.8 \mathrm{~s}$ as shown in Figure. 8(a), the DC voltage (VO) settles at the set reference. A reduction of $25 \%$ is observed in the estimated torque (Te), that exist for a transient period of $0.5 \mathrm{~s}$ as shown in Figure $8(\mathrm{~b})$. The speed response is observed to be similar to that achieved for proposed DECDTC configureuration. Thus, the response obtained by using DEC under voltage sag condition is better as compared to that of PI controller.

2. Current Harmonic and Power Factor response at the supply end

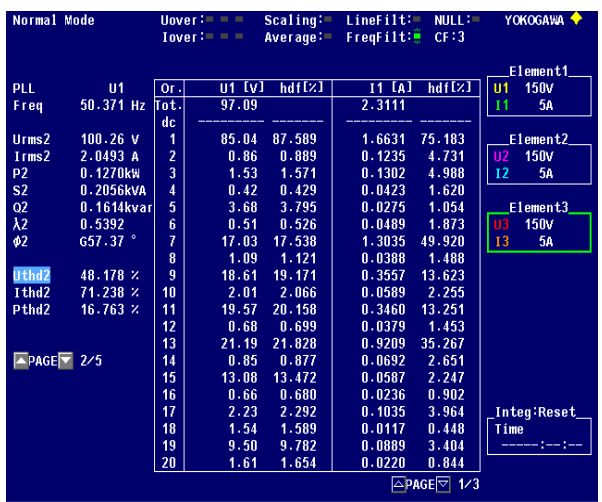

a. with conventional inverter and DTC approach

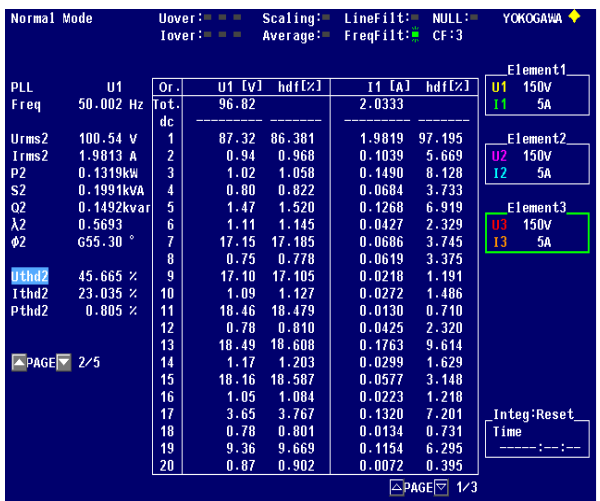

b. with qZSI and PI-DTC approach

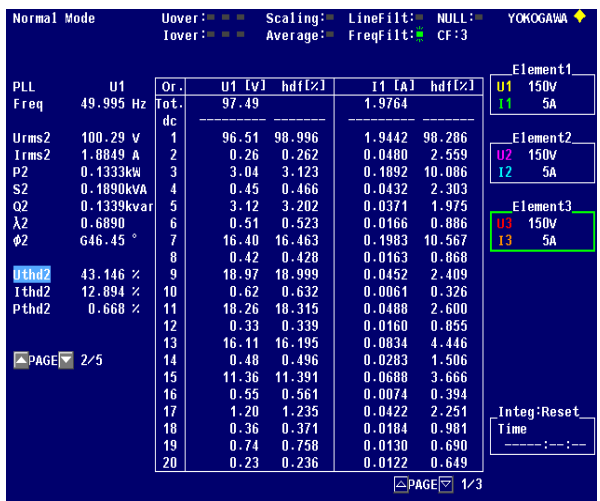

c. with qZSI and CC-DEC based DTC approach

Figure. 9 Power Analyzer results at the source 
The prime focus of the proposed of CC-DEC control approach is to maintain the THD (Total harmonic distortion) and power factor at the source end, thus avoiding the drives contribution in power quality deterioration and helping to maintain the voltage profile for other connected loads. The effect of using different conFigureuration and control approach is observed by using a power analyzer equipment at the three-phase source side, i.e. at the input end of three-phase diode rectifier. It indicates the voltage $\left(\mathrm{U}_{\mathrm{rms}}\right)$, current $\left(\mathrm{I}_{\mathrm{rms} 2}\right)$, apparent power $\left(\mathrm{S}_{2}\right)$, active power $\left(\mathrm{P}_{2}\right)$, reactive power $\left(\mathrm{Q}_{2}\right)$, power factor $\left(\lambda_{2}\right)$ and THD content $\left(\mathrm{I}_{\mathrm{thd} 2}\right)$ of each of the three phases as shown in Figure.9. One of the three-phases is considered for these measurements and observations for three specific condition of the five-phase drive system, i.e. one with conventional inverter and DTC approach, other two for the same qZSI system with PI-DTC approach and proposed CC-DEC based DTC approach. All the observations are made for a fixed loading condition and fixed input per phase voltage of $100 \mathrm{~V}$ (RMS).

Figure 9(a) indicates the source end parameters with conventional inverter configuration where the current THD content is very high (around $71 \%$ ) which creates a lot of distortion at the supply side and also greatly contributes in reduction of power factor (around 0.54). The source end parameters with qZSI configuration based on PI-DTC approach is shown in Figure. 9(b). It shows that the current THD content reduces to around $23 \%$ and power factor improves to 0.56. Figure. 9(c) illustrates the effect of proposed CC-DEC approach with current THD reduced to $12 \%$ and power factor further improved to around 0.68 . This clearly indicates the effectiveness of the proposed approach with qZSI configuration for the source side in terms of harmonic reduction and power factor improvement along with the improvement in drives performance.

\section{Conclusion}

An experimental analysis of current controlled DEC-DTC based qZSI fed five-phase IM drive is presented in this paper. Since, these sag situations are highly vulnerable for a sensitive application, which is mostly the applicable zone of multi-phase drives, it results in heavy impact from financial and performance aspects. A DEC based duty cycle " $D$ " estimation technique is proposed for designing of qZSI controller. Centered on mathematical model of qZSI and DEC based error diminishing concept, the equation for duty cycle " $\mathrm{D}$ " is developed. This duty cycle is then combined with SVM of DTC, in order to implement the proposed control concept for five-phase IM. An experimental investigation is carried out for five-phase drive in the form of a comparative investigation amongst DTC with conventional inverter, PIDTC with qZSI and proposed current controlled DEC-DTC based qZSI under voltage sag condition. The results of proposed control implementation for five-phase IM drive system, is observed to be much better, in reference to output DC-voltage, torque and speed, as illustrated through results. Also, source current THD reduction from $71 \%$ to $12 \%$ and power factor improvement at the supply end is observed from 0.54 to 0.68 with the proposed controller, using a power analyzer device. Thus, experimental analysis exhibits a reliable and impressive approach for effective functioning of five-phase IM drive with reduction in its power quality polluting impact on the supply side.

\section{References}

[1]. Emil Levi, Federico Barrero and Mario J. Duran, " Multiphase Machines and DrivesRevisited," IEEE Trans. Industrial Electronics, vol. 63, no. 1, pp. 429 - 432, Jan. 2016.

[2]. J. M. Apsley, S. Williamson, A. C. Smith and M. Barnes, "Induction motor performance as a function of phase number," IEE Proceedings - Electric Power Applications, vol. 153, no. 6 , November 2006.

[3]. G.K Singh, "Multi-phase induction machine drive research-a survey," Electric Power Systems Research, vol. 61, no. 2, pp. 139-147, 2002.

[4]. E. Levi, "Advances in Converter Control and Innovative Exploitation of Additional Degrees of Freedom for Multiphase Machines," IEEE Transactions on Industrial Electronics, vol. 63, no. 1, pp. 433-448, Jan. 2016. 
[5]. R. Bojoi, M. G. Neacsu and A. Tenconi, "Analysis and survey of multi-phase power electronic converter topologies for the more electric aircraft applications," International Symposium on Power Electronics, Electrical Drives, Automation and Motion, Sorrento, pp. 440-445, 2012.

[6]. M. J. Duran, J. A. Riveros, F. Barrero, H. Guzman and J. Prieto, "Reduction of CommonMode Voltage in Five-Phase Induction Motor Drives Using Predictive Control Techniques," IEEE Transactions on Industry Applications, vol. 48, no. 6, pp. 2059-2067, Dec. 2012.

[7]. H. Guzman et al., "Comparative Study of Predictive and Resonant Controllers in FaultTolerant Five-Phase Induction Motor Drives," IEEE Transactions on Industrial Electronics, vol. 63, no. 1, pp. 606-617, Jan. 2016.

[8]. L. A. Pereira, S. Haffner, L. F. A. Pereira and R. S. da Rosa, "Performance comparison of five phase and three phase induction machines under steady state including losses and saturation," IECON 2013 - 39th Annual Conference of the IEEE Industrial Electronics Society, Vienna, pp. 3036-3041, 2013.

[9]. B. H. Rocha and M. Madrigal, "Analysis of Performance of Adjustable-Speed Drives during Voltage Sags," IEEE Latin America Transactions, vol. 3, no. 5, pp. 39-46, Dec. 2005 .

[10]. M. Petronijevic, B. Veselic, N. Mitrovic, V. Kostic and B. Jeftenic, "Comparative study of unsymmetrical voltage sag effects on adjustable speed induction motor drives," IET Electric Power Applications, vol. 5, no. 5, pp. 432-442, May 2011.

[11]. S. Z. Djokic, K. Stockman, J. V. Milanovic, J. J. M. Desmet and R. Belmans, "Sensitivity of AC adjustable speed drives to voltage sags and short interruptions," IEEE Transactions on Power Delivery, vol. 20, no. 1, pp. 494-505, Jan. 2005.

[12]. C. L. Su, C. J. Chen and C. C. Lee, "Fast Evaluation Methods for Voltage Sags in Ship Electrical Power Systems," IEEE Transactions on Industry Applications, vol. 49, no. 1, pp. 233-241, Feb. 2013.

[13]. P. Liu and H. P. Liu, "Permanent-magnet synchronous motor drive system for electric vehicles using bidirectional z-source inverter," IET Electrical Systems in Transportation, vol. 2, no. 4, pp. 178-185, December 2012.

[14]. O. Ellabban, J. Van Mierlo and P. Lataire, "Direct torque controlled space vector modulated induction motor fed by a Z-source inverter for electric vehicles," International Conference on Power Engineering, Energy and Electrical Drives, Malaga, pp. 1-7, 2011.

[15]. A. A. Abduallah, M. Meraj, M. Al-Hitmi and A. Iqbal, "Space vector pulse width modulation control techniques for a five-phase quasi-impedance source inverter," IET Electric Power Applications, vol. 12, no. 3, pp. 379-387, 2018.

[16]. Y Liu et al., Impedance source power electronic converters, John Wiley and Sons, 2016.

[17]. S. Yang, F. Z. Peng, Q. Lei, R. Inoshita and Z. Qian, "Current-Fed Quasi-Z-Source Inverter with Voltage Buck-Boost and Regeneration Capability," IEEE Transactions on Industry Applications, vol. 47, no. 2, pp. 882-892, April 2011.

[18]. O. Ellabban and H. Abu-Rub, "Field oriented control of a five phase induction motor fey by a Z-source inverter," IEEE International Conference on Industrial Technology (ICIT), Cape Town, pp. 1624-1629, 2013.

[19]. K. C. R. Nisha and S. Jain, "PV powered performance enhanced three-stage cascaded quasi Z-source inverter fed induction motor drive," International Conference on Circuits, Power and Computing Technologies [ICCPCT-2015], Nagercoil, pp. 1-7, 2015.

[20]. S. Dongsen, G. Baoming, W. Weiliang, B. Daqiang, F. Z. Peng and A. R. Haitham, "Quasi-Z source inverter based pole-phase modulation machine drive system," International Conference on Electrical Machines and Systems, Beijing, pp. 1-6, 2011.

[21]. G. Tajima, T. Kosaka and N. Matsui, "Experimental studies on drive performances of wound field synchronous motor drive integrated with ZSI," IEEE Applied Power Electronics Conference and Exposition (APEC), Charlotte, NC, pp. 262-269, 2015. 
[22]. Y. N. Tatte and M. V. Aware, "Torque Ripple and Harmonic Current Reduction in a Three-Level Inverter-Fed Direct-Torque-Controlled Five-Phase Induction Motor," IEEE Transactions on Industrial Electronics, vol. 64, no. 7, pp. 5265-5275, July 2017.

[23]. Abdesslam Lokriti, Issam Salhi and Said Doubabi, "IM direct torque control with no flux distortion and no static torque error," ISA Transactions, vol. 59, pp. 256-267, Sept. 2015.

[24]. Taheri, "Harmonic reduction of Direct Torque Control of six-phase induction motor," ISA Transactions, vol. 63, pp. 299-314, March 2016.

[25]. J. A. Riveros, M. J. Durán, F. Barrero and S. Toral, "Direct torque control for five-phase induction motor drives with reduced common-mode voltage," IECON - 38th Annual Conference on IEEE Industrial Electronics Society, Montreal, QC, pp. 3616-3621, 2012.

[26]. B. S. Khaldi, H. Abu-Rub, A. Iqbal, R. Kennel, M. O. Mahmoudi and D. Boukhetala, "Comparison study between a simple sensorless method and adaptive observer for DTCSVM five-phase induction motor drive," IEEE International Conference on Industrial Technology, Athens, pp. 743-748, 2012.

[27]. Y. N. Tatte, M. V. Aware, J. K. Pandit and R. Nemade, "Performance Improvement of Three-Level Five-Phase Inverter-Fed DTC-Controlled Five-Phase Induction Motor During Low-Speed Operation," IEEE Transactions on Industry Applications, vol. 54, no. 3, pp. 2349-2357, May 2018.

[28]. A. K. Panda, P. R. Mohanty, N. Patnaik and T. Penthia, "Closed-Loop Controlled Cascaded Current Controlled Dynamic Evolution Control (CC-DEC) based Voltage Doubler (VD) PFC Converter for Improved Dynamic Performance," IEEE Journal of Emerging and Selected Topics in Power Electronics (Future Issue).

[29]. Pratap Ranjan Mohanty and Anup Kumar Panda, "A nonlinear control scheme based on dynamic evolution path theory for improved dynamic performance of boost PFC converter working on nonlinear features," ISA Transactions, vol. 65, pp. 254-261, Nov. 2016.

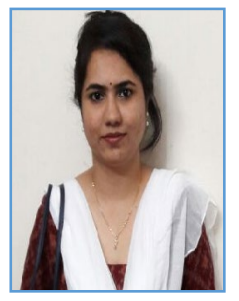

Richa Pandey received the B.E in Electrical Engineering from CCET, Bhilai, India and M.E in Power Electronics, CCET, Bhilai, India in 2010 and 2013 respectively. She is currently pursuing Ph.D. in National Institute of Technology Rourkela, India. Her current research area includes multi-phase machine drives and multi-level inverter.

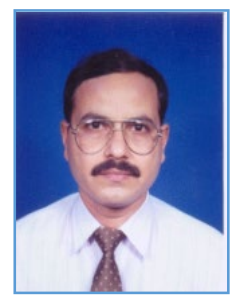

Anup Kumar Panda received the B.Tech in Electrical Engineering from Sambalpur University, India, M.Tech in Power Electronics and Drives from Indian Institute of Technology, Kharagpur, India and Ph.D.from Utkal University in 1987, 1993 and 2001 respectively. In 1990 he joined as a lecturer in IGIT, Sarang, served there for eleven years and then in January 2001 joined National Institute of Technology, Rourkela as an Assistant Professor and currently continuing as a Professor in the Department of Electrical Engineering, National Institute of Technology Rourkela. He has published over hundred articles in journals and conferences. He has completed two MHRD projects and one NaMPET project. Guided seven Ph.D. scholars and presently guiding ten scholars in the area of Power Electronics \& Drives. He is a Fellow of Institute of Engineering and Technology UK, Insttitute of Engineers India and Institute of Electronics and Telecommunication Engineering. He is also a senior member of IEEE USA. 
His research interest includes Design of high frequency power conversion circuits and Applications of Soft Computing Techniques, improvement in Multilevel Converter Topology, Power Factor Improvement, Power quality Improvement in power system and Electric drives.

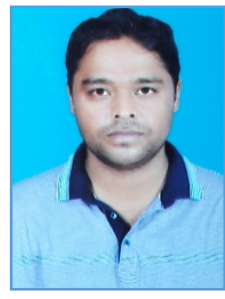

Nishant Patnaik received the B.Tech in Electrical Engineering from BIT Durg, India and M.Tech in Power Electronics and Drives from Kalinga Institute of Industrial Technology, Bhubaneswar, India in 2006 and 2009 respectively. He completed his Ph.D from National Institute of Technology Rourkela, India in 2017. He has published several articles in reputed journals and conferences. His current research includes power quality improvement and application of power electronics with non-conventional energy sources. 